\title{
PRINTO scholarships: the Italian experience
}

\section{Pablo Garcia Munitis}

\author{
Address: 9N${ }^{\circ} 140$ CP 1900. La Plata, Argentina \\ Email: Pablo Garcia Munitis - poligm9@hotmail.com
}

Published: 27 September 2007

Pediatric Rheumatology 2007, 5:18 doi:10.1 I86/1546-0096-5-18

This article is available from: http://www.ped-rheum.com/content/5/l/l8

(C) 2007 Munitis; licensee BioMed Central Ltd.

This is an Open Access article distributed under the terms of the Creative Commons Attribution License (http://creativecommons.org/licenses/by/2.0), which permits unrestricted use, distribution, and reproduction in any medium, provided the original work is properly cited.
Received: II June 2007

Accepted: 27 September 2007

\begin{abstract}
The increasing availability of the internet allows physicians to access actualized medical information quickly and easily, but it is not comparable with the possibility of working in a well known international medical centre.

International collaboration (scholarships, courses and research), such as the PRINTO alpha project, allows professionals not only to increase and share scientific knowledge and experiences but also to integrate into a working team in a foreign country which leads to an understanding among cultures.

PRINTO has set up a scientific and technical collaborative research network in Paediatric Rheumatology for Latin American physicians.
\end{abstract}

Having been a fellow of the alpha project at "Gianina Gaslini Hospital" in Genova, Italy, I read the article in your journal written by Nicolino Ruperto and Alberto Martini [1] and I thought that the paragraphs referring to "Research training in Paediatric rheumatology" could have been treated in more detail, considering both the scientific and human aspects of the Alpha Project.

The purpose of the Paediatric Rheumatology International trial organization (PRINTO) is to foster, facilitate and conduct high quality research in the field of paediatric rheumatology (PRINTO bylaws) [2]. This program was set up on the basis that paediatric rheumatic diseases are rare, consequently, qualified physicians are needed to conduct multicenter collaborative studies on an international scale, to obtain clinically and statistically valid results.

Twenty four fellowships were available for Latin American professionals. Those fellows who participated in Genova Alpha Project not only succeeded in paediatric rheumatic research but also went through an invaluable human and cultural experience [2].

The scientific program included:

1. Clinical activities

a. Daily inpatients visit.

b. Weekly meeting with Prof. Martini, director of the unit, and the staff physicians.

c. Acquisition of techniques for intra-articular injections in the main joints, either blinded or ultrasound-driven.

\section{Courses}

a. Course in Clinical trials and applied statistics, held by Dr Nicolino Ruperto MD, MPH. 
b. Course in outcome assessment for the paediatric rheumatic diseases, held by Dr Angelo Ravelli MD.

c. Course in Basic and Intermediate Biostatistics and Epidemiology, held by Dr Angela Pistorio, MD, PhD.

3. Research activities with active participation in research projects, some of them published in different medical journals $[3,4]$.

Furthermore we participated in a Language and Culture course, where we could learn the Italian language and lots of things concerning Italian culture and history.

What I do want also to emphasize is the host's cordiality, dedication and professionalism, and their positive disposition to integrate the fellows to a working team in a foreign country which, no doubt, leads to an understanding among nations.

My most sincere gratitude to all of them and a strong wish that this experience could be repeated.

\section{References}

I. Ruperto N, Martini A: International Networks in Pediatric Rheumatology: The example of PRINTO. Pediatric Rheumatology Online Journal 2004, 2(2): 108-II3.

2. Pediatric rheumatology international trials organisation [http://www.Printo.it/]

3. Ruperto N Garcia-Munitis P, Villa L, Pesce M, Aggarwal A, Fasth A, Avcin T, Bae SC, Balogh Z, Li C, De Inocencio J, Dibra M, Dolezalova P, El Miedany Y, Flato B, Harjacek M, Huppertz HI, Kanakoudi-Tsakalidou F, Wulffraat N, Lahdenne P, Melo-Gomes JA, Mihaylova D, Nielsen S, Nikishina I, Ozdogan H, Pagava K, Panaviene V, Prieur AM, Romicka AM, Rumba I, Shafaie N, Susic G, Takei S, Uziel Y, Vesely R, Woo P, Martini A, for the Paediatric Rheumatology International Trials Organisation (PRINTO) and the Paediatric Rheumatology European Society (PRES): PRINTO/PRES international web-site for families of children with rheumatic diseases. Ann Rheum Dis 2005, 64:1101-II06 [http://www.pediatric-rheumatology.printo.it]. Epub 2005 Mar 10

4. Garcia-Munitis P, Bandeira M, Pistorio A, Magni-Manzoni S, Ruperto $\mathrm{N}$, Schivo A, Martini A, Ravelli A: Level of agreement between children, parents and physicians in rating pain intensity in juvenile idiopathic arthritis. Arthritis Rheum 2006, 55:177-183.
Publish with Bio Med Central and every scientist can read your work free of charge

"BioMed Central will be the most significant development for disseminating the results of biomedical research in our lifetime. "

Sir Paul Nurse, Cancer Research UK

Your research papers will be:

- available free of charge to the entire biomedical community

- peer reviewed and published immediately upon acceptance

- cited in PubMed and archived on PubMed Central

- yours - you keep the copyright

Submit your manuscript here:

http://www.biomedcentral.com/info/publishing_adv.asp
BioMedcentral 